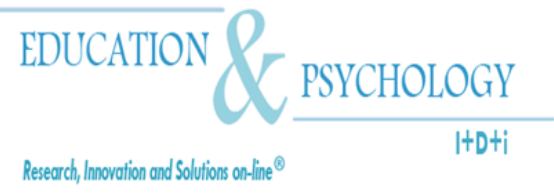

\section{Electronic Journal of Research}

in Educational Psychology

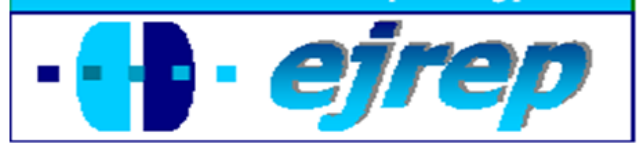

Editorial EOS

\title{
Students' Self-Esteem and their Perception of Teacher Behavior: A Study of Between-Class Ability Grouping
}

\author{
Prihadi Kususanto, Hairul Nizam Ismail \\ \& Hazri Jamil
}

School of Educational Studies - Universiti Sains Malaysia

Penang

\section{Malaysia}

Correspondence: Prihadi Kususanto. School of Educational Studies, Universiti Sains Malaysia. 11800 USM, Penang, Malaysia. E-mail: personalitymagics@gmail.com

(C) Education \& Psychology $\mathrm{I}+\mathrm{D}+\mathrm{i}$ and Editorial EOS (Spain) 


\begin{abstract}
Introduction. Between-class ability grouping practice in Malaysian Secondary Schools was studied in order to find the influence students' perception on their teachers' behavior on their self-esteem. Students' perception on teachers' behaviors were divided into two categories: controlling students' behavior to avoid disciplinary matters and supporting students' academic achievements.
\end{abstract}

Method. 302 students from four public secondary schools were selected to participate in this study. Self-esteem levels of the students were measured using the Rosenberg Self-Esteem Scale. All scales were translated into local language and internal consistency reliability scores. Mean and t-test were used to analyze the difference of self-esteem between two groups as well as the difference of students' perception on teachers' behavior between two groups. For analyzing the mentioned differences within groups, mean and paired t-test were used. Influence of students' perceptions on teachers' behavior on students' self-esteem were analysed with multiple regression.

Results. Results showed that students from high achievers' groups scored significantly higher in self-esteem compared to the students from low achievers' groups. A significant difference in perception on teachers' behavior between the students in the high and low achievers' groups was found; students from high-achievers' groups perceived their teachers to be more supportive while the other groups perceived their teachers to be more controlling. Amongst high-achievers groups, self-esteem were significantly influenced by perception on teachers', supporting behavior, while amongst low-achievers 'groups, self-esteem were significantly influenced by perception on teachers' controlling behavior.

Discussion or Conclusion: It is indicated that teachers might have different preconceived idea on the students based on their classrooms assignment. This difference is visible through their overt behavior, which was then perceived by the students, and in turn, influences the students' self-esteem.

Keywords: self-esteem; teachers' behavior; students' perceptions, achievement.

Received: 04/05/10 Initial Acceptance: 04/20/10 Definitive Acceptance: 06/03/10 


\title{
La autoestima de los alumnos y su percepción del comportamiento del profesor: un estudio de agrupación entre clases por capacidades
}

\begin{abstract}
Resumen
Introducción. La agrupación por habilida en las escuelas malayas de Educación Secundaria se ha estudiado para conocer la influencia de la percepción del alumnado sobre el comportamiento del profesorado y su influencia en la autoestima del alumnado. La percepción del alumnado sobre el comportamiento docente se ha dividido en dos categorías: control del comportamiento para facilitar la disciplina y apoyo al alumnado en su desarrollo académico.
\end{abstract}

Método. Un total de 302 estudiantes de escuelas públicas de secundaria fueron seleccionadas para participar en el estudio. Los niveles de autoestima se midieron utilizando la Escala de Autoestima de Rosenberg. Todas las escalas fueron traducidas y analizadas para probar la validez interna. El análisis de la media y la $\mathrm{t}$ de Student fueron utilizadas para valorar la diferencia en autoestima de los grupos así como las diferentes percepciones del profesorado que tenía el alumnado. Para el análisis de tales diferencias se utilizó el análisis de comparación de medias. La influencia de la percepción de los estudiantes sobre la autoestima fue analizada mediante una análisis de regresión múltiple.

Resultados. Los resultados muestran que los estudiantes con buen redimiento puntuan significativamente más alto en autoestima que aquellos con bajo rendimiento. Se observa una diferencia significativa en perpcepción del profesorado entre los estudiantes de alto y bajo rendimiento. Los estudiantes de alto redimiento perciben que el profesorado les apoya más en tanto que los otros grupos lo perciben principalemente como controladores. Entre los estudiantes de alto rendmiento, la autoestima aparece influenciada por la percepción que tienen del profesor como facilitador, en tanto que, el grupo de bajo rendimiento presenta una autoestima significativamente influenciada por el comportamiento de control del docente.

Discusíon y Conclusiones. El profesorado tiene ideas preconcebidas sobre el alumnado. Tal diferencia es visible en relación con su comportamiento que es percibido por el alumnado y que a su vez influye en la autoestima de los estudiantes.

Keywords: autoestima, comportamiento docente, percepción del alumnado, rendimiento.

Recibido: 05/04/10 Aceptación Inicial: 20/04/10 Aceptación Definitiva: 03/06/10 


\section{Introduction}

Between-class ability grouping (BCAG) is the common practice in public secondary schools in Malaysia (Hassan, Sulaiman, \& Abiddin, 2009). Aimed at creating conducive learning environment for students of quite similar achievement level, public secondary schools in Malaysia grouped their students based on their previous overall ability reports; therefore one batch of students would contained highest-achievers' class (HAC) at one end, and lowest-achievers' class (LAC) at the other end. Such practice is in line with the definition of BCAG as the practice of grouping students in separate classes based on ability level with assumption that individuals have a certain level of general intelligence that predicts their achievement across all subjects (Ireson \& Hallam, 2001; Slavin, 2006). This paper is discussing the correlation between students assigned to HAC and their counterparts assigned to LAC in terms of their perception on teachers' behavior, and its influence on their self-esteem.

Despite its common practice in some countries, some studies found that BCAG practices did not have any positive influence towards students' academic achievement (Goodland, 1983; Oakes 1985; Slavin 2006). Furthermore, several studies indicated that teachers' different attitude towards each students' group significantly predicted students' academic achievements and non-academic traits (Al-Fadhli \& Singh, 2006; Good, 1981; Tong, 2002).

\section{Teachers' behavior}

Recent studies shown that teachers who favor BCAG tend to be focused on academic achievements, while teachers who favor non-ability grouping classes tend to be more student-centered, with a greater concern for the all-round development, learning by discovery and practical experience, and dislike selective examinations (Hallam, et al.., 2002; Kulik, 2004).

Other studies on BCAG noted that teachers have different expectations on each group of students. Myers (2008) stated that teachers would likely to expect students from the HAC to be eager to improve academic achievement, and students from the 
LAC would likely to have disciplinary problems. Each of this expectancy led the teachers' to behave in such ways towards each group of students. Oakes (1985) discovered that relationships between teachers and students in LAC are likely to be centered on avoiding student disruptions, hostility, and alienation, while in HAC; the relationships appeared to be focused on students' academic achievements.

Thomas L. Good (1981) found that towards slow or low-performing students, teachers were likely to pay less attention, call less frequently, give less time to answer questions, provide less follow-up questions in problem situations, criticize more frequently for incorrect answers, praise less often for correct or marginal responses, give less feedback, demand less effort, and interrupt the performance more frequently. A qualitative study by Hung Siu Tong (2002) from University of Hongkong concluded that the perspectives of the teachers gradually take shape and then reflected in their instruction and attitudes towards their class, and eventually the students will perform as they were expected. Al-Fadhli and Singh (2006), from Jackson State University and Tougaloo College, studied 102 teachers from various secondary schools in Mississippi, and found that towards the students from HAC, teachers based their expectation on students' ability, and towards the students from LAC, teachers based their expectations on personal characteristics.

Based on the finding of Good (1981) and Oakes (1985), we divided students' perception on teachers' behavior into two categories. The first one is called Controlling Behavior, which was defined as the students' perception that their teachers were focused on controlling students' behavior to avoid general disciplinary problems; and the second one is called Supportive Behavior, which was defined as the students' perception that their teachers were focused on supporting the improvement of academic achievements.

Students' self-esteem

Self-esteem refers to one's overall evaluation of one's self-worth or self-image (Maslow, 1954; Rogers, 1980). Self-esteem is influenced by whether the culture around an individual values one's particular characteristics and capabilities (Bandura, 1997). Adequate level of self-esteem would elevate students' beliefs in their own ability, which 
in turn, would elevate their performance, both academically and non-academically (Rendall et al., 2009). this study, students' self-esteem refers to students' overall evaluation of their self-worth, including their beliefs on how well they would perform as individuals or as a member of society, both academically and non-academically. Refering to a statement that a person with high self-esteem in one area also tends to have high self-esteem in the other areas as well (Larsen \& Buss, 2008), it could be concluded that in a significant degree, self-esteem would give an impact on the students' academic achievement and their future success. Therefore, it seemed to be critical to explore the influence of teachers' behavior in the classroom on students' self-esteem.

Symbolic Interaction Theory, which started by Cooley (1912) and renewed by Stryker (2002) stated that evaluation of individuals on themselves (self-esteem) is based on their perception on others' behavior. In other words, self-esteem is the judgment of personal worthiness that is conveyed to others by each individual in what one says and what one does not say; by what one does and what one does not; nevertheless, it could be studied in their manifestations as overt behavior (Coopersmith, 1967). Referring to the symbolic interaction theory and Coopersmith's statement, parenting style and attachment levels (Önder et al., 2010), as well as teachers' expectancy, plays an important role to predict students' self-esteem. However, teachers' expectancy would be perceived by the students through teachers' overt behavior; hence, instead of measuring teachers' expectancy towards to students, this study measure students' perception on their teachers' behavior as a predictor of their self-esteem. Several research questions were investigated by this study:

1. Is there any difference between students from HAC and LAC in term of their perception on teachers' behavior?

2. Is there any difference between students from HAC and LAC in term of their self-esteem levels?

3. Is there any correlation between students' perception on teachers' behavior on students' self-esteem levels? 


\section{Method}

Participants

A purposive sampling method was used in this study and 302 students were recruited as participants, all of them were at their fourth year of secondary school (late 16 to 17 years old). The participants comprised 153 students from HAC and 149 students from LAC from 4 Public Secondary Schools in in Johor, southern part of peninsular Malaysia.

Instruments

Self-esteem is measured by the Rosenberg Self-Esteem Scale, developed by Morris Rosenberg (1965). The scale is a 10-item self-report measure of global selfesteem. It consists of 10 statements related to overall feelings of self-worth or selfacceptance. The items are answered on a four-point scale ranging from strongly agree to strongly disagree. Internal consistency of the questionnaire is assessed using Cronbach's alpha, and the instrument showed the reliability of .74

In order to measure student's perception on teachers' behavior, we developed two scales based on the findings of Good (1981) and Oakes (1985). Content validity of the scales was determined by a panel of external experts who has adequate information and knowledge in the domain of classroom interaction and social psychology from UniversitiTeknologi Malaysia. The panel reviewed the items for content, clarity, and appropriateness. The students' perception on teachers' controlling behavior and students' perception on teachers' supportive behavior questionnaires are 4 points scale with 20 survey items. Each engagement domain is represented by a subscale. There are 10 items for each construct. The students' response scale ranges from Strongly Disagree $(=1)$ to Strongly Agree (=4). Internal consistency of the questionnaire is assessed using Cronbach's alpha, and each instrument showed the reliability of .77 for controlling behavior and .76 for supportive behavior. Table 1 shows the reliability of each instrument. 
Table 1. Reliability of Scales

\begin{tabular}{cr}
\hline Instruments & Cronbach's Alpha \\
\hline Self-esteem & .74 \\
Perception on teachers' controlling behavior & .77 \\
Perception on teachers' supporting behavior & .76 \\
\hline
\end{tabular}

\section{Procedure}

Supported by principals and teachers of each school, three sets of questionnaire have been distributed to the participants. The first set was the Rosenberg Self-esteem Scale, the second one was the scale to measure students' perception on teachers' controlling behavior, and the last one was the scale to measure students' perception on teachers' supportive behavior. Each set contained its original version in English and its translated version. The translation to Malaysian language has been done by using back translation method, supported by some lecturers of TESL (Teaching English as Second Language) from the faculty of education, Universiti Teknologi Malaysia.

\section{Research Design and Statistical Analysis}

This research is framed within a quantitative, empirical-analytical design. This descriptive study compares data obtained from applying the questionnaire to samples of 153 students from HAC and 149 students from LAC in four Public Secondary Schools in Johor, Malaysia. Statistical analyses were performed using SPSS v17.0.

The first analyses have made to see the difference between students from LAC and HAC in term of their perception on both teachers' controlling and supportive behavior by using mean and t-test. These analyses were meant to see how students from each group perceived their teachers' behavior. In order to make sure about each group's perception on teachers' behavior, mean and paired t-test were used to analise the difference between teachers' supporting and controlling behavior within each group. Eventually, multiple regression method was used to analyse the influence of dominant perceived behavior to the self-esteem levels of each group and both groups altogether. 


\section{Results}

The difference between students from HAC and LAC in term of perception on teachers' controlling behavior

Difference between two means was tested using independent sample t-test, because the distribution of the scores is normal in both groups. And the result found that there is a significant difference between perception on teachers' controlling behavior of students from high and low achievers' classes $(\mathrm{t}=3.45, \mathrm{df}=299.9, p=.001)$. As shown in Table 2, the mean score for HAC students are 23.93, which is lower than the mean score for LAC, which is 25.43 .

Table 2. Difference in perception on teachers' controlling behavior between students' groups

\begin{tabular}{cccccc}
\hline & Class & $\mathrm{N}$ & Mean & sd & independent sample t-test \\
\hline $\begin{array}{c}\text { Perception on teach- } \\
\text { ers' controlling behav- } \\
\quad \text { ior }\end{array}$ & HAC & 149 & 23.93 & 3.71 & \\
$\begin{array}{c}\text { LAC } \\
\begin{array}{c}\text { ion } \\
\hline\end{array}\end{array}$ & 153 & 25.43 & 3.87 & $\mathrm{t}=3.45, \mathrm{df}=299.93, \mathrm{p}=.001$ \\
\hline
\end{tabular}

There is a significant difference in perceptions on teachers' controlling behavior between students from the high and low-achievers' classes. According to what the students from LAC have perceived, teachers were behaving in such ways that are likely to control the classroom and were more concerned about discipline matters in order to void disruption, instead of encouraging or supporting for academic improvement. On the opposite, students from HAC, which scored lower than their counterparts from LAC, did not significantly perceived their teachers' behavior as controlling their behavior.

The difference between students from HAC and LAC in term of perception on teachers' supporting behavior

Table 3 showed that the mean score for HAC students is 25.33; this is significantly higher than the mean score for LAC, which is 24.00 . The distribution of the scores is normal in both groups; thereby the significance of the difference between two 
means was tested using independent sample $\mathrm{t}$-test, and it found that there is a significant difference between perception on teachers' controlling behavior of students from high and low achievers' classes $(\mathrm{t}=3.05, \mathrm{df}=298.51, p=.003)$

Table 3. Difference in perception on teachers' supporting behavior between students' groups

\begin{tabular}{|c|c|c|c|c|c|}
\hline & Class & $\mathrm{N}$ & Mean & sd & independent sample t-test \\
\hline \multirow{2}{*}{$\begin{array}{l}\text { Perception on teach- } \\
\text { ers' supporting behav- } \\
\text { ior }\end{array}$} & HAC & 149 & 25.33 & 3.87 & \multirow[b]{2}{*}{$\mathrm{t}=3.05, \mathrm{df}=298.51, \mathrm{p} .003$} \\
\hline & $\mathrm{LAC}$ & 153 & 24.00 & 3.70 & \\
\hline
\end{tabular}

Significant difference was found in perception on teachers' supporting behavior between the students in the high and low-achievers' classes of BCAG. It shows that students from the HAC perceived that their teachers to be supportive to improve their academic achievements, while their counterparts in the LAC did not significantly perceived so.

The difference within students from the LAC in term of perception on teachers' supporting and controlling behavior

Perception of the students from LAC on their teachers' behavior was compared between the perception on controlling behavior and supportive behavior. The mean scores were tested using paired sample t-test, because the compared scores were normally distributed. As seen in Table 4, the result shows that the mean value for controlling behavior is higher $(M=25.43)$ than the supportive behavior $(M=24.00)$ there is a significant difference within the students from LAC in term of their perception on teachers' behavior $(\mathrm{p}=0.00)$.

Table 4. Difference of perception on teachers' supporting / controlling behavior within students from LAC

\begin{tabular}{lcccc}
\hline & $\mathrm{N}$ & Mean & Std. Deviation & paired sample t-test \\
\hline Controlling Behavior & 153 & 25.43 & 3.87 & $\mathrm{t}=4.81, \mathrm{df}=152, \mathrm{p}=.00$ \\
Supporting Behavior & 153 & 24.00 & 3.70 & \\
\hline
\end{tabular}


The difference within the students from the LAC perception on teachers' behavior is significant between controlling and supportive behavior. In other words, based on teachers' behavior, they perceived that their teachers are more into controlling students' behavior to maintain the discipline than supporting students to improve their academic achievements. The difference between those two kinds of perceptions on teachers' behavior is significant $(\mathrm{p}=.00)$.

The difference between perception on teachers' supporting behavior and teachers' controlling behavior within students from the LAC.

This test was comparing the mean scores of perception on teachers' supportive behavior and teachers' controlling behavior within the students from the high-achievers' classes. The mean value for perception on teachers' controlling behavior is lower $(\mathrm{M}=23.93)$ than perception on teachers' supportive behavior (25.33). Paired-sample ttest is used in this test because the distribution of the scores is normal in both types of perceptions, and the data came from the same group of sample. The result in Table 5 shows that there is a significant difference within the students from high-achievers classes in term of their perception on teachers' behavior $(\mathrm{p}=0.00)$.

Table 5. Difference of perception on teachers' supporting / controlling behavior within students from HAC

\begin{tabular}{lllcc}
\hline & $\mathrm{N}$ & Mean & Std. Deviation & paired sample t-test \\
\hline Controlling Behavior & 149 & 23.93 & 3.71 & $\mathrm{t}=-4.56, \mathrm{df}=148, \mathrm{p}=.00$ \\
Supporting Behavior & 149 & 25.33 & 3.87 & \\
\hline
\end{tabular}

The difference within the students from the HAC in term of their perception on teachers' behavior is significance between controlling and supportive behavior. In other words, based on teachers' behavior, students from the HAC perceived that teachers are more into supporting students to improve academic achievements than controlling students' behavior to maintain discipline.

It could be concluded from the results that students from the LAC were likely to perceive their teacher' behavior to be more likely to take control of students' discipline, while students from the high-achievers classes were tend to perceive their teachers to be 
more likely to support students to improve academic achievements. Next analyses were conducted on the students based on their respective dominant perception on teachers' behavior. Students from LAC were analysed whether their self-esteem levels influenced by the teachers' controlling behavior, while their counterparts from high-achievers classes were analysed whether their self-esteem levels influenced by the teachers' supportive behavior.

The influence of students' perception on teachers' controlling on students' self-esteem in $L A C$

As shown in Table 6, among students from the LAC, results showed that the adjusted $\left(\mathrm{R}^{2}=.017 ; \mathrm{df}=(1,15) ; \mathrm{F}=4.32\right)$. It means that students' perception of teachers' controlling behavior can explain $1.7 \%$ of the variance in students' self-esteem, and the test is significant $(\mathrm{p}=.04)$.

Table 6. Influence of students' perception on teachers' controlling behavior on selfesteem in $L A C$

\begin{tabular}{ccc}
\hline Variable & Beta Value $(\beta)$ & $\mathrm{P}$ \\
\hline $\begin{array}{c}\text { Students' perception on teachers' controlling behavior } \\
\text { (in LAC) }\end{array}$ & .17 & .04 \\
\hline
\end{tabular}

The results also showed that the beta $(\beta)$ was .17 , and the $p$ value was .04 . the $p$ was lower than .05 , which means that the influence was significant. The way the students from the LAC value themselves is significantly influenced by their perception on teachers' controlling behavior. In other words, the more they perceive that their teachers tried to control their discipline, the higher they value themselves. On the other hand, their perception that their teachers are supporting an improvement on academic achievement was not found to be significant.

The influence of students ' perception on teachers' supportive behavior on students' selfesteem in high-achievers' classes.

Stepwise multiple regression test was also done to the students from the highachievers' classes. Results showed that the adjusted $\left[\mathrm{R}^{2}=.38 ; \mathrm{df}=(1,147) ; \mathrm{F}=6.78\right.$; 
$\mathrm{p}=.01]$. It was indicated that the test is significant and might explain $3.8 \%$ of the data variance. Table 7 showed the values obtained from the analysis.

Table 7. Influence of students' perception on teachers' supporting behavior on selfesteem in the high-achievers classes

\begin{tabular}{ccc}
\hline Variable & Beta Value $(\beta)$ & $\mathrm{P}$ \\
\hline $\begin{array}{c}\text { Students' perception on teachers' supporting behavior } \\
\text { (in HAC) }\end{array}$ & .21 & .01 \\
\hline
\end{tabular}

The test excluded the variable of perception on teachers' controlling behavior due to its insignificance $(\beta=-.09 ; p=.33)$. The beta value $(\beta)$ of the significant variable was .21 , which indicated an influence, and the p value was .01 , which showed that the influence is significant. In other words, students' from HAC would value themselves higher when they perceived that their teachers were giving them support to improve their academic achievements.

The influence of students' perception of teachers' behavior as controlling and supportive behavior on students' self-esteem in both groups.

When applied to the pooled group of students from both HAC and LAC, results showed that the adjusted $\left[\mathrm{R}^{2}=.02 ; \mathrm{df}=(1,300) ; \mathrm{F}=7.93 ; \mathrm{p}=.005\right]$. The predictor variables can explain $2 \%$ of the data variance, and the test is significant. As shown in Table 8 , the results also showed that the beta $(\beta)$ was .16 , and the $p$ value was .005 . Table 8 shows the result obtained from the analysis.

Table 8. Influence of students' perception on teachers' controlling and supporting behavior on students' self-esteem in both groups (pooled data).

\begin{tabular}{ccc}
\hline Variable & Beta Value $(\beta)$ & $\mathrm{P}$ \\
\hline $\begin{array}{c}\text { Students' perception on teachers' supporting behavior } \\
\text { (Pooled groups of students) }\end{array}$ & .16 & .005 \\
\hline
\end{tabular}

It could be seen that the significance was found to be stastistically high ( $\mathrm{p}=$ .005). The predictor variable of students' perception on teachers' controlling behavior was excluded in the stepwise method. It can be concluded that students would value 
themselves higher when they perceived that the teachers supports them to improve academic achievement. Oppositely, their self-esteem level would not get any higher or lower when they perceived that their teachers behaved in such way to control their behavior to avoid disciplinary problems.

\section{Discussions and conclusions}

The variable of students' perception on teachers' behavior were assumed to have different effect on the different group of students and to a pooled group, where two groups of students were combined. Therefore, the data analyses were done separately. It was found that there is a significant influence of students' perception on teachers' behavior on the self-esteem levels of the students from the HAC ( $\mathrm{p}=.01$, by teachers' supporting behavior), LAC ( $\mathrm{p}=.039$, by teachers' controlling behavior), and a pooled group of both types of students ( $\mathrm{p}=.005$, by teachers' supportive behavior). It can be concluded into a single statement, that in general, students' perceptions on teachers' behaviors have significant influence on their self-esteem levels.

Findings of this study stated that students from the LAC of the public secondary schools in Malaysia perceived that their teachers behave in such ways to control their behavior, in order to minimize disciplinary problems. The way they value themselves (self-esteem) was significantly influenced by their perception on teachers' controlling behavior; the more they perceive that their teachers try to control their behavior, the higher they will value themselves. However, the influence was considered as weak; the beta value was .21 , which means that it takes 1 point of perception to increase their selfesteem for 0.21 points. This might be due to a situation where they did not perceive their teachers to be significantly supportive; hence, the only attention they can get from their teachers was in the form of controlling behavior. On the other hand, their perception on teachers' supportive behavior did not have significant influence on their selfesteem, because they did not think that their teachers were being supportive.

Students from HAC would value themselves higher when they perceive their teachers support them in terms of academic achievements. This might prove that being placed in the HAC is not the only factor to gain higher levels of self-esteem; it takes 
supportive teachers to develop their self-esteem to a higher level. Compared to the students' from LAC, their perception on teachers' controlling behavior did not have any significant influence towards their self-esteem levels. It indicated that when they perceived that their teachers tried to control their behavior, they would not change their way to value themselves.

This study found that perception on teachers' behavior has a significant influence on the self-esteem levels of the students. This finding supports the theories and findings of the previous works which stated that it is not the evaluation of oneself alone that generated self-esteem; how a person thinks others would value him/her would also generate his/her self-esteem (Bandura 1997; Burns, 1975, 1982; Coopersmith 1967; Horrocks \& Jackson 1972; Myers 2008; Stryker, 2002).

Other studies by Good (1981) and Slavin (1987), which noted that teachers assigned in LAC seem to have lower expectations on the students than teachers assigned in LAC were as well supported by the findings of this study. Teachers' expectations would affect their behaviors towards the students, who might perceived the teachers' behaviors as supportive or controlling, and in turn, the influence will get into their way of giving value to themselves, which is called self-esteem.

\section{Practical Implications}

Findings of this study showed that the influence of the students' perception on teachers' behavior could explain some percentage of their self-esteem, and due to the pvalues found, it was clearly shown that the influences are significant.

Some recent researches done in Malaysia about grouping students stated that BCAG is needed to deliver better instructions (Hassan et al., 2009; Yahaya et al., 2005). In a system where BCAG is kept being applied, it is important to have different instructional strategies regarding the difference between high and low-achievers' students. Nevertheless, teachers should at least try not to let themselves biased by the label given to the students by the practice of BCAG. With knowledge that students' self-esteem levels are significantly influenced by their perceptions on teachers' behaviors, then it 
should be better to keep the balance between controlling students' behavior and supporting academic achievement in both groups.

Teachers should be aware that the labels given by BCAG system to the students might represent their previous academic ability, but it does not represent their potential, especially in non-academic aspects. Still, all of the students deserve good expectations from the teachers, due to its significant influence to students' self-esteem. The instructional method might be different between high and low-achievers' students; nevertheless, some efforts should be done in order to keep the students from perceiving that their teachers are either extremely discipline or extremely controlling. Some specific methods to improve the self-esteem levels of the students from LAC are as well important to take into consideration.

\section{Future researches}

Due to the similar grouping system, same research might be conducted in other countries that practice BCAG in their schools. Some extraneous variables that could have influenced the results that have been excluded in this study might as well be investigated. They might be demographic factors such as gender, socio economic status, place (urban or rural area), and school status (government or private) might have possibly influenced the variables in this study. Another important variable to investigate is the teachers' expectancy towards the students in each group and its influence on teachers' behavior based on self-fulfilling prophecy (Pygmalion effect) theory (Rosenthal \& Jacobson, 1992 and Rosenthal, 2002). There might be difference in self-esteem between urban and rural students, or female and male students. It is suggested to add more demographic factors to the future research in order to get more accurate and representative results. It is also considered be important to investigate the occurance of biased perspective of teachers in BCAG-practicing schools. 


\section{References}

Al-Fadhli, H., \& Singh, M. (2006). Teachers' expectancy and efficacy as correlates of school achievement in Delta, Mississipi. National Evaluation Institute Conference. Dallas: National Evaluation Insitute Conference.

Bandura, A. (1997). Self-efficacy: The excercise of control. New York, NY: Freeman.

Burns, R. B. (1982). Self-concept development and education. Dorchester: Holt, Rinehart, and Winston.

Byrne, B. M. (1988). Adolescent self-concept, ability grouping, and social comparison: reexamining academic track. Atlanta: American Psychological Association.

Cooley, C. (1912). Human Nature and the Social Order. New York: Scribners.

Coopersmith, S. (1967). The Antecedents of Self-Esteem. San Francisco: Freeman.

Good, T. L. (1981). Teacher's expectancy and students' perception: a decade of research. Educational Leadership , 38, 415-422.

Goodland, J. I. (1983). A place called school. New York: McGraw-Hill.

Hassan, A., Sulaiman, T., \& Abiddin, N. Z. (2009). The requirement of grouping technique in English lesson in meeting the demand of philosophy of education in malaysia. The Journal of International Social Research , 294-306.

Hendricks, K. B. (2009). The impact of ability grouping on the achievement, selfefficacy, and classroom perceptions of gifted elementary students. Walden University Journal .

Horrocks, J. E., \& Jackson, D. W. (1972). Self and Role: A Theory of Self-Process and Role Behavior. Boston: Houghton Mifflin Company.

Ireson, J., \& Hallam, S. (2001). Ability Grouping in Education . London: Sage.

Kulik, J. A. (2004). Grouping, Tracking, and De-Tracking. In H. J. Walberg, A. J. Reynolds, \& M. C. Wang (Eds.), Can Unlike Students Learn Together? Grade Retention, Tracking, and Grouping, 157-182. Greenwich: Information Age Publishing Inc.

Larsen, R. J., \& Buss, D. M. (2008). Personality Psychology: Domains of Knowledge abou Human Nature. New York, NY: McGraw-Hill.

Maslow, A. (1954). Motivation and Personality. New York: Harper \& Row.

Myers, D. G. (2008). Social Psychology. Holland, MI: McGraw Hill.

Oakes, J. (1985). Keeping Track: How Schools Structure Inequality. New Haven, CT: Yale University. 
Önder, F.C., Kurdök, O., \& Işik, E. (2010). High school students' career decisionmaking pattern across parenting styles and parental attachment levels. Electronic Journal of Research in Educational Psychology, 8(1), 263-280.

Rendall, N.D., Wesson, C., Anderson, L., \& Bould, E. (2009) Studetns' Goal Achievement: Exploring Individual and Situational Factors. Electronic Journal of Research in Educational Psychology, 7(3), 1031-1052

Rogers, C. R. (1980). A way of being. Boston: Houghton Mifflin.

Rosenthal, R. (2002). Covert communication in classrooms, clinics, courtrooms, and cubiclres. American Psychologist, 57, 839-849.

Rosenthal, R., \& Jacobson, L. (1992). Pygmalion in the classroom: expanded edition. New York : Irvington.

Salinitri, D. (2006). Streaming in secondary schools: effects on students' self-efficacy from the perspectives of the students, teachers, administrators, and counsellors. Windsor: University of Windsor.

Slavin, R. E. (1987). Ability Grouping and Student Achievement in Elementary Schools. Review of Educational Research , 57, 293-336.

Slavin, R. E. (2006). Educational Psychology; Theory \& Practice 8th edition. Boston: Allyn \& Bacon.

Stryker, S. (2002). Symbolic Interactionism: A Social Structural Version. Caldwell, NJ: Blackburn Press.

Tong, H. S. (2002). A Comparison of the perception of teachers assigned to teach higher and lower ability group. Hongkong: University of Hongkong.

Yahaya, A., Suboh, A., Zakariya, Z., \& Yahya, F. (2005). Aplikasi Kognitif dalam Pendidikan [Cognitive Application in Education]. Bentong: PTS Professional Publishing, Sdn. Bhd. 